\title{
SURVEI MOTIVASI BELAJAR PESERTA DIDIK SMP TERHADAP PENGADAAN \\ PRAKTIKUM PADA MATA PELAJARAN IPA
}

\author{
Aisyah Nurul Janah, Aninda Wulan .S, Musawwir Usman, Jumadi
}

Program Studi Pendidikan Sains, Program Magister, Universitas Negeri Yogyakarta

Jalan Colombo Yogyakarta. 1, Karangmalang, Yogyakarta, 55281, Yogyakarta

\section{aisyahnuruj@gmail.com}

\begin{abstract}
Abstrak
Penelitian ini bertujuan untuk mengetahui pengaruh pengadaan praktikum IPA terhadap motivasi belajar peserta didik. Penelitian ini dilakukan pada peserta didik SMP sebagai sampel. Metode penelitian yang digunakan adalah kuantitatif deskriptif. Instrumen pengumpulan data berupa angket motivasi belajar. Data dianalisis menggunakan statistic deskriptif. Berdasarkan hasil penelitian, pengadaan praktikum IPA terhadap motivasi belajar peserta didik ditunjukkan dengan nilai presentase pada setiap indikator sebesar 77\%, 77\%, 76\% dan 78\%. Hasil survei motivasi belajar peserta didik terhadap pengadaan praktikum IPA diperoleh rata-rata presentase sebesar $77 \%$ yang masuk dalam kategori baik terhadap motivasi peserta didik.
\end{abstract}

Kata kunci: praktikum, motivasi, peserta didik

\section{PENDAHULUAN}

IPA merupakan ilmu yang memiliki karakteristik khusus yaitu mempelajari fenomena alam yang faktual (Asih Widi Wisudawati, 2014:22). IPA adalah suatu kumpulan teori yang sistematis, penerapannya secara umum terbatas pada gejala-gejala alam, lahir dan berkembang melalui metode ilmiah seperti observasi dan eksperimen serta menuntut sikap ilmiah seperti rasa ingin tahu, terbuka, jujur, dan sebagainya (Trianto, 2011). Fenomena alam yang faktual di lingkungan menjadi sumber belajar bagi peserta didik untuk meningkatkan pengetahuan melalui proses pembelajaran IPA. Pembelajaran IPA menekankan pada pengalaman langsung untuk mengembangkan kompetensi agar peserta didik mampu memahami alam sekitar melalui proses mencari tahu sehingga dapat membantu siswa untuk memperoleh pemahaman yang lebih mendalam tentang alam sekitar (BSNP, 2007). IPA sebagai ilmu pengetahuan yang mempelajari tentang fenomena alam, maka diperlukan proses pembelajaran yang dapat mengaktifkan peserta 
didik melalui kegiatan yang dapat menghidupkan suasana belajar yang menyenangkan. Salah satu strategi pembelajaran IPA yang dapat memicu pemahaman peserta didik yaitu pembelajaran berbasis praktikum atau percobaan.

Praktikum adalah kegiatan yang bertujuan untuk membekali peserta didik agar lebih dapat memahami teori dan praktik (Mahmudatun, 2017). Kegiatan praktikum dapat melibatkan peserta didik dalam merencanakan dan melakukan percobaan, menemukan fakta, mengumpulkan data, mengendalikan variabel, dan memecahkan masalah. Hamid (2011) mendefinisikan bahwa metode praktikum adalah metode pemberian kesempatan kepada peserta didik baik secara perorangan maupun kelompok untuk dilatih melakukan suatu proses ilmiah. Menurut Hurrahman (2011) target dari metode praktikum supaya peserta didik dapat membuktikan kebenaran dari teori-teori konsep yang berlaku serta peserta didik mendapat kepuasan dari hasil belajarnya. Sanjaya (2009) mengemukakan bahwa pengetahuan yang dimiliki peserta didik akan bermakna jika dilandasi rasa ingin tahu. Melalui kegiatan percobaan, peserta didik diberi kesempatan untuk mengalami dan membuktikan sendiri sesuatu yang dipelajarinya sehingga pengetahuan yang dimilikinya menjadi bermakna. Menurut Sudjana (2009) kegiatan percobaan akan membantu peserta didik dalam mengembangkan kecakapan dan mendapatkan pengetahuan dari lingkungan sosial. Kegiatan pembelajaran yang menarik dapat membuat peserta didik lebih semangat dan memotivasinya dalam proses belajar (Susanti, 2013).

Motivasi belajar merupakan suatu yang sangat penting untuk kelangsungan kegiatan belajar serta berperan penting penting dalam pencapaian prestasi belajar. Menurut Wlodkowsky dalam Sugihartono (2003), motivasi merupakan suatu kondisi yang menyebabkan atau menimbulkan perilaku tertentu dan yang memberi arah dan ketahanan pada tingkah laku tersebut. Motivasi adalah suatu usaha yang disadari untuk menggerakkan, mengarahkan, dan menjaga tingkah laku seseorang agar ia terdorong untuk bertindak melakukan sesuatu sehingga mencapai hasil atau tujuan tertentu (Ngalim purwanto, 2014). Sedangkan Dimyati dan Mudjiono (2006) mengemukakan bahwa motivasi dipandang sebagai dorongan mental yang menggerakan dan mengarahkan perilaku manusia, termasuk perilaku belajar. Oemar (2011) menjelaskan bahwa motivasi adalah perubahan energi dalam diri (pribadi) seseorang yang ditandai dengan timbulnya perasaan dan reaksi untuk mencapai tujuan. Motivasi adalah proses yang memberi semangat, arah, dan kegigihan perilaku. Artinya perilaku yang termotivasi adalah perilaku yang penuh dengan energi, mempunyai tujuan atau terarah terarah dan bertahan lama. 


\section{METODE}

Objek yang digunakan dalam penelitian ini adalah objek alami. Objek alami merupakan objek yang tidak dimanipulasi dan tidak dipengaruhi oleh peneliti. Penelitian dilakukan dengan cara subjek diberi angket tentang pengadaan praktikum pada mata pelajaran IPA terhadap motivasi peserta didik. Instrumen pengumpulan data yang digunakan oleh peneliti adalah berupa pemberian angket. Pemberian angket kepada siswa bertujuan untuk mengetahui respon atau tanggapan peserta didik terhadap pengadaan praktikum yang dilakukan. Hasil survei diukur dari angket yang diberikan kepada peserta didik dan kemudian diukur menggunakan rumus persentase. angket yang diberikan kepada siswa yang terdiri dari 15 pernyataan tentang motivasi peserta didik terkait pengadaan praktikum. Adapun kisi-kisi angket motivasi belajar peserta didik pada Tabel 1 berikut ini.

Tabel 2. Kisi - Kisi Angket Motivasi Belajar Peserta Didik

\begin{tabular}{|c|c|c|}
\hline No. & Aspek & Indikator \\
\hline \multirow{4}{*}{1} & \multirow{4}{*}{$\begin{array}{l}\text { Perhatian } \\
\text { (attention) }\end{array}$} & Minat siswa dalam praktikum \\
\hline & & Ketertarikan siswa pada praktikum \\
\hline & & Keterlibatan siswa dalam praktikum \\
\hline & & Rasa ingin tahu terhadap materi yang ada pada kegiatan praktikum \\
\hline \multirow{3}{*}{2} & \multirow{3}{*}{$\begin{array}{l}\text { Relevansi } \\
\text { (relevance) }\end{array}$} & Relevansi tema materi dengan kegiatan praktikum \\
\hline & & Relevansi manfaat praktikum IPA dengan kebutuhan siswa \\
\hline & & Relevansi metode dengan materi \\
\hline \multirow{5}{*}{3} & \multirow{5}{*}{$\begin{array}{l}\text { Percaya Diri } \\
\text { (confidence) }\end{array}$} & Percaya diri dalam melakukan praktikum \\
\hline & & Percaya diri dalam mempelajari materi \\
\hline & & Percaya diri dalam berdiskusi \\
\hline & & Percaya diri dalam pemahaman materi \\
\hline & & Percaya diri dalam keberhasilan \\
\hline \multirow{3}{*}{4} & \multirow{3}{*}{$\begin{array}{l}\text { Kepuasan } \\
\text { (satisfaction) }\end{array}$} & Perasaan puas terhadap pelaksanaan praktikum \\
\hline & & Perasaan senang terhadap pemahaman materi setelah praktikum \\
\hline & & Perasaan puas terhadap hasil belajar yang dicapai \\
\hline
\end{tabular}

Diadaptasi: John Keller (Sugihartono, 2007).

Data pemberian angket kemudian dianalisis secara deskriptif kuantitatif untuk mengetahui respon peserta didik dengan menghitung presentase jawaban peserta didik terhadap aspek-aspek respon siswa yang dinyatakan dengan rumus sebagai berikut:

$$
\text { Presentase }(\%)=\frac{\text { jumlah skor yang diperoleh }}{\text { jumlah skor keseluruhan }} \times 100 \%
$$


Pengukuran komponen dilakukan secara deskriptif kuantitatif dengan menggunakan persentase skor rata-rata dari setiap aspek, rumus yang digunakan sebagai berikut.

$$
\text { Presentase }(\%)=\frac{j u m l a h \text { skor setiap aspek }}{\text { jumlah keseluruhan setiap aspek }} \times 100 \%
$$

(Sumber: Suharsimi Arikunto, 2008)

Data kuantitatif yang berbentuk presentase skor diubah menjadi data kualitatif sesuai dengan kriteria Tabel 1.

Tabel 1. Presentase Kriteria Motivasi Belajar

\begin{tabular}{|l|l|c|l|}
\hline No & Tingkat Penguasaan $(\%)$ & Nilai Huruf & Kategori/Predikat \\
\hline 1. & $86-100$ & A & Sangat Baik \\
\hline 2. & $76-85$ & B & Baik \\
\hline 3. & $66-75$ & C & Cukup \\
\hline 4. & $55-65$ & D & Kurang \\
\hline 5. & $\leq 54$ & E & Sangat Kurang \\
\hline
\end{tabular}

(Sumber: Ngalim Purwanto, 2002).

\section{HASIL DAN PEMBAHASAN}

Data hasil survei diperoleh beberapa hasil yang mewakili tentang pengadaan praktikum terhadap motivasi peserta didik. Secara ringkas hasil survei motivasi belajar peserta didik disajikan dalam Tabel 3.

Tabel 3. Data Motivasi Belajar Peserta Didik Berdasarkan Indikator

\begin{tabular}{|l|c|c|c|}
\hline \multicolumn{1}{|c|}{ Indikator Motivasi } & \multirow{2}{*}{$\begin{array}{c}\text { Presentase } \\
\text { Keberhasilan (\%) }\end{array}$} & Taraf Keberhasilan & Nilai dengan Huruf \\
\cline { 3 - 4 } & 77 & Baik & $\mathrm{B}$ \\
\hline Perhatian (attention) & 77 & Baik & $\mathrm{B}$ \\
\hline Relevansi (relevance) & 76 & Baik & $\mathrm{B}$ \\
\hline Percaya Diri (confidence) & 78 & Baik & $\mathrm{B}$ \\
\hline Kepuasan (satisfaction) & & & \\
\hline
\end{tabular}

Berdasarkan Tabel 3 diketahui bahwa persentase rerata motivasi belajar peserta didik dengan pengadaan praktikum sebesar $77 \%$ dengan taraf keberhasilan termasuk kategori baik. Presentase motivasi belajar peserta didik pada setiap indikator motivasi belajar yaitu: 1) Perhatian (attention) sebesar 77\% dengan kategori baik, 2) Indikator Relevansi (relevance) sebesar 77\% dengan kategori baik, 3) Indikator Percaya Diri (confidence) sebesar 76\% dengan kategori baik, dan 4) Indikator Kepuasan (satisfaction) sebesar 78\% dengan taraf keberhasilan kategori baik. 
Presentase tertinggi terletak pada indikator kepuasan sebesar $78 \%$ dan persentase terendah terletak pada indikator percaya diri sebesar $76 \%$, terlihat bahwa perbandingan presentase dari setiap indikator tidak terpaut jauh.

Motivasi berperan penting dalam proses belajar, sehingga motivasi juga mempengaruhi kegiatan praktikum. Susanto dalam Fajarianingtyas (2013) menyatakan bahwa motivasi belajar adalah suatu yang mendorong siswa untuk dapat melakukan kegiatan belajar. Namun, motivasi tidak akan muncul begitu saja dalam diri peserta didik. Motivasi yang baik ialah motivasi yang muncul secara internal dari peserta didik itu sendiri. Peserta didik harus sudah sudah menyadari sebelumnya bahwa dirinya harus berhasil dan harus mengikuti proses pembelajaran secara tekun dan baik. Motivasi internal akan muncul karena kesadaran peserta didik sejak awal (Agustina, 2015).

\section{KESIMPULAN DAN SARAN}

Hasil survei tentang motivasi belajar peserta didik SMP terhadap pengadaan praktikum pada mata pelajaran IPA di beberapa sekolah, menunjukkan bahwa pengadaan praktikum IPA memotivasi peserta didik dengan presentase hasil presentase pada setiap indikator sebesar $77 \%$, $77 \%, 76 \%, 78 \%$ dan diperoleh rata-rata presentase sebesar 77\% yang masuk dalam kategori baik terhadap motivasi peserta didik. Penelitian ini hanya berupa data survei yang dapat digunakan sebagai referensi untuk penelitian selanjutnya. Penelitian ini tidak dipisahkan berdasarkan gender dan faktor eksternal lainnya. Berdasarkan penelitian yang telah dilakukan, maka untuk penelitian lebih lanjut sebaiknya membahas faktor lain yang dapat mempengarungi variabel tersebut.

\section{DAFTAR PUSTAKA}

Agustina. (2015). Motivasi Belajar dan Hasil Belajar Psikomotor Siswa MTs Sunan Ampel Siman

Kepung Kelas IX dalam Aktivitas Praktikum IPA. Cendekia, 9(2): 217-222.

Asih Widi Wisudawati. (2013). Metodologi Pembelajaran IPA. Yogyakarta: Bumi Aksara.

BSNP. (2007). Kurikulum Tingkat Satuan Pendidikan. Jakarta: BNSP Depiknas.

Dimyati dan Mudjiono. (2006). Belajar Dan Pembelajaran. Jakarta: Rineka Cipta.

Hamid, Darmadi. (2011). Metode Penelitian Pendidikan. Bandung: Alfabeta.

Mahmudatun, Umi. (2017). Metode Praktikum untuk Meningkatkan Pemahaman dan Hasil

Belajar Siswa Kelas V MI YPPI 1945 Babat pada Materi Zat Tunggal dan Campuran. Proceeding Biology Education Conference 14 (1): 62 - 68. 
Ngalim, Purwanto. (2002). Prinsip-prinsip dan Teknik Evaluasi Pembelajaran. Bandung: Rosdakarya.

Oemar, Hamalik. (2011). Proses Belajar Mengajar. Jakarta: PT Bumi Aksara.

Sanjaya, Wina. (2009). Strategi Pembelajaran Berorientasi Standar Proses Pendidikan. Jakarta: Kencana Prenada Media Group.

Sudjana. (2009). Penilaian Hasil Proses Belajar Mengajar. Bandung: PT. Remaja Rosdakarya. Sugihartono. (2007). Psikologi Pendidikan. Yogyakarta: UNY Press.

Suharsimi Arikunto. (2013). Dasar-dasar Evaluasi Pendidikan. Jakarta: Rineka Cipta.

Susanti, Rahmi. (2013). Pengaruh Penerapan Pembelajaran Berbasis Masalah pada Praktikum

Fotosinteses dan Respirasi untuk Meningkatkan Kemampuan Generik Sains Mahasiswa Biologi

FKIP Universitas Riau. Universitas Riau: Palembang.

Trianto. (2011). Model Pembelajaran Terpadu. Jakarta: Bumi Aksara. 